\title{
"A deficit of decent work as a current trend in the development of social and labor sphere in Ukraine"
}

\begin{tabular}{|c|c|}
\hline AUTHORS & $\begin{array}{l}\text { Anatoliy Kolot (D https://orcid.org/0000-0002-4393-9806 } \\
\text { R https://publons.com/researcher/E-4275-2018/ } \\
\text { Oksana Herasymenko } \mathbb{D} \text { https://orcid.org/0000-0002-1122-1189 } \\
\text { R http://www.researcherid.com/rid/K-8003-2018 }\end{array}$ \\
\hline ARTICLE INFO & $\begin{array}{l}\text { Anatoliy Kolot and Oksana Herasymenko (2017). A deficit of decent work as a } \\
\text { current trend in the development of social and labor sphere in Ukraine. } \\
\text { Knowledge and Performance Management, 1(1), 5-18. } \\
\text { doi:10.21511/kpm.01(1).2017.01 }\end{array}$ \\
\hline DOI & http://dx.doi.org/10.21511/kpm.01(1).2017.01 \\
\hline RELEASED ON & Thursday, 05 January 2017 \\
\hline RECEIVED ON & Tuesday, 25 October 2016 \\
\hline ACCEPTED ON & Sunday, 18 December 2016 \\
\hline LICENSE & $\begin{array}{l}(c) \text { EY } \\
\text { This work is licensed under a Creative Commons Attribution } 4.0 \text { International } \\
\text { License }\end{array}$ \\
\hline JOURNAL & "Knowledge and Performance Management" \\
\hline ISSN PRINT & $2543-5507$ \\
\hline PUBLISHER & Sp. z o.o. Kozmenko Science Publishing \\
\hline FOUNDER & Sp. z o.o. Kozmenko Science Publishing \\
\hline$\sigma^{\circ}$ & $\begin{array}{l}\text { ニ: } \\
\text { 二= }\end{array}$ \\
\hline NUMBER OF REFERENCES & NUMBER OF FIGURES \\
\hline 35 & 2 \\
\hline
\end{tabular}

(c) The author(s) 2022. This publication is an open access article. 


\title{
A deficit of decent work as a current trend in the development of social and labor sphere in Ukraine
}

\begin{abstract}
Sustainable development of the national economy is impossible without the creation of conditions for safe, high-quality, efficient work. The relevance of the study is explained by the need of methodological substantiation and development of theoretical and applied instruments for ensuring decent work. The scientific and practical significance of the study is to distinguish the forms of manifestation, to establish the causes of decent work deficit within the new economy and to determine the vectors of its overcoming in Ukraine. The results of the study are focused on generalization of the modern trends in the development of social and labor sphere in Ukraine and improvement of the concept of decent work to be used in practice in order to achieve progress in the social and labor sphere. The subject of the study is theoretical and applied principles of the concept of decent work as a basis for the development of mechanisms and instruments to overcome the deficit of decent work. The methodological platform of the study is formed by the general scientific and special methods: theoretical generalization; abstract and logical synthesis; induction and deduction; classification and typology; comparative and structural analysis that would allow carrying out multidirectional research of the progress (regress) in the sphere of work on different levels. The methodological basis for achieving this goal is the systematic and interdisciplinary approaches to the study of socio-economic indicators of decent work deficit. The purpose of the study is a scientific and theoretical substantiation of the decent work deficit and determination of strategic guidelines for its overcoming in Ukraine. In the article the authors present their view on the institute of decent work. Forms of manifestation and causes of decent work deficit are presented. The content of the article shows the relationship of the deficit of decent work and the precariat phenomenon. The authors present their vision of the concept of decent work as a strategic development of social and labor sphere and a major road towards elimination of the deficit of decent work in Ukraine.
\end{abstract}

Keywords: social and labor sphere, decent work, decent work deficit, precariat, the concept of decent work.

JEL Classification: A13.

Received on: $25^{\text {th }}$ of October, 2016.

Accepted on: $18^{\text {th }}$ of December, 2016.

\section{Introduction}

Over the past two decades, the Ukrainian society has experienced large-scale, multilevel changes that have transformed almost all components of social and economic life. However, these changes did not bring stability to the society, did not add stable positive dynamics to social and economic development, did not eliminate the asymmetry of economic results of business entities, on the one hand, and social achievements of the absolute majority of the population - on the other. Instead, new risks emerged and previously existing risks deepened, the field of instability segments grew and unpredictability of the effects of economic activity increased. The dynamic of instability and asymmetry in its various manifestations is observed on the example of social and labor sphere, which is the institutional environment for the functioning and development of social and labor relations, which are becoming increasingly unhealthy.

\section{(C) Anatoliy Kolot, Oksana Herasymenko, 2017.}

Anatoliy Kolot, Doctor of Economics, Professor, Vice Rector for Research and Academic Affairs, Vadym Hetman Kyiv National Economic University, Ukraine.

Oksana Herasymenko, Ph.D, Associate professor, Personnel Management, Sociology and Psychology Department, Vadym Hetman Kyiv National Economic University, Ukraine.

This is an Open Access article, distributed under the terms of the Creative Commons Attribution 4.0 International license, which permits unrestricted re-use, distribution, and reproduction in any medium, provided the original work is properly cited.
In the new economy, an economically active person faces both new opportunities and new challenges. Among the latter is a growing problem of decent work.

The study by the authors of the issues of social and labor sphere led to the following conclusion: if the basic problems of social and labor sphere are viewed through the prism of their origin, checks and limitations, the main problem on the way towards sustainable development of social and labor sphere is a deficit of decent work - the work, the result of which is the creation of all the necessary things for the existence, prosperity and development of the humankind; the work that is associated with progress in all areas of economic and social life.

Preservation of the decent work deficit is a sign of failures in political, economic and social decisions made by politicians and management at all levels. At the same time, this is the result of profound changes in the sources and the driving forces of development that cause the formation of a new multi-level economy, the impact of which on human development is ambiguous and contradictory.

The main purpose of the research is a scientific and theoretical substantiation of the decent work deficit and determination of strategic guidelines for its overcoming in Ukraine. 


\section{Methodology}

Scientists and practitioners have offered various conceptual and methodological approaches to the criteria, indicators, and other components of the phenomenon of decent work helping to understand its essence and content. However, the scientific and practical foundation of decent work requires methodological and interdisciplinary confirmation. The importance of a new, impartial, scientific prudent understanding of issues of decent work is self-evident. The theoretical and applied instruments presented in the literature sources and materials of international organizations are often a collection of political slogans, wishes, general opinions, views on developing a new format of social and labor sphere based on the dominance of decent work. The existing fragmentation, vagueness and ambiguity in the interpretation of the basic principles and mechanisms of development of the institution of decent work generate a lot of unregulated, unsystematic characteristics and indicators of decent work indicators presented in numerous publications and methodological research. This is a vivid example when evidently correct, socially relevant ideas, principles and concepts do not have a clear, methodologically calibrated foundation. Without the latter, it is difficult to expect a unifying guiding idea, which would have consolidated the actions of all social forces to achieve a new quality of working life.

In conducting the study, a number of general and special methods were used: theoretical generalization; abstract logic; synthesis; induction and deduction; comparative and structural analysis. Methodological basis for achieving this goal became the systematic and interdisciplinary approaches in studying the attributes of the decent work deficit and determining the principle ways to ensure decent work.

\section{Literature review}

The issue of decent work was studied in the numerous articles and other publications, the vast majority of which begins with a reference to the idea of decent work, which was first published by the International Labor Organization (ILO) in 1999. In the report of the ILO's Director-General Juan Somavia during the 87 session of the International Labor Conference decent work was defined as a work with protected rights of the workers, which provides adequate income and ensures social security (Decent work, 1999). Also decent work embodies sufficient work in the sense that each individual has a full and free access to the opportunities to earn and generate revenue. In addition, compliance with the principles of decent work means new perspectives in terms of economic and social development, new opportunities in which employment, income and social protection can be achieved without compromizing the rights of workers and social standards (Decent work: Some Strategic Challenges Ahead, 2008). According to the ILO methodology, progress in the labor sphere is evaluated according to the indicators of employment, social protection, respect for workers' rights, social dialogue. For 19 countries of different continents, a "profile" of decent work was developed, which makes it possible to identify progress and highlight problem areas in the functioning of social and labor sphere (Measuring decent work. Decent Work Country Profiles).

Certainly, an important accomplishment in initiating and promoting the idea of decent work in the globalized world belongs to the International Labor Organization. Speeches of its heads, reports circulated as documents of the ILO, numerous resolutions and other legal and methodological materials of this respected international organization really contributed to the idea of decent work reaching the masses, while on the national levels, the first programs of decent work implementation emerged.

There is a significant contribution of the world's scientific and expert community to the development of methodological instruments evaluating decent work globally, organization of statistical surveys and monitoring of the implementation of its principles taking into account the level of development of national economies. Thus, scientific and applied studies authored by Anker, Egger, Mehran, Ritter, and Chernyshev (2002), contain six indicators, eleven criteria and thirty indices characterizing decent work from the position of equal opportunities for men and women to obtain decent and productive jobs under conditions of freedom, equity, security and human dignity.

In addition, potential indicators are proposed that can be applied in the event of changes or innovations regarding the collection of statistical information (Anker et al., 2002). A distinctive feature of the approach developed by Beskond, Shatejne and Mehran is a methodology of selection of indicators, namely, the assessment of decent work for socially vulnerable layers of the population: the young, the elderly, children between the ages from 10 to 14 , women (Bescond, Chataignier, \& Mehran, 2003). The integral index of decent work, including the component of safety and security of employees, was proposed by Bonnet, Figueiredo, and Standing (2003). According to Fields (2003), the peculiarity of identification of decent work is the assessment of the availability of employment in the context of development. 
In the Ukrainian scientific community, these issues are considered from the standpoint of the state's legal policy as a prerequisite for effective and productive work (Hostiuk, 2016); implementation of the concept of decent work in the socio-economic development of Ukraine (Zhadan, 2014); classification of factors ensuring decent work (Humeniuk, 2011); components of the concept of decent work, including safe working conditions (Husiev, 2014); identification of problems regarding employment opportunities, the solution of which is recognized as a key component of ensuring decent work (Il'ienko, 2014); adaptation of conceptual and methodological universal aspects of assessing decent work to the national labor market and the national legislation of Ukraine (Kalachova, 2006); the study of moral characteristics of decent work in the context of globalization (Kaplina, 2013); mechanism of ensuring decent work on the principles of corporate social responsibility (Lebediev, 2014); the impact of decent work on the building of socially oriented economy (Rudakova, 2012); ensuring preconditions for the realization of the concept of decent work through increased competitiveness of human capital assets (Shaul's'ka, 2014).

However, the scientific and practical foundation of decent work is insufficiently substantiated, and methodologically corroborated. The scientific community often ignores the indisputable fact that a deficit of decent work is a global problem today.

\section{Contemporary trends in the development of social and work-related sphere on a global scale}

It should be noted that asymmetries in economic and social development, instability in the broadest sense, de-socialization of relationships in the work sphere, the reduction of social cohesion, the spread of social exclusion - these are all unwanted realities of the new century's beginning.

The expansion of the scope of the new economy, the formation of which is associated with post-capitalist and post-industrial society, with informatics and communication society, with information and service economies or economies of the tertiary sector, are accompanied by many contradictory trends in the field of human development and the functioning of social and labor sphere on a global scale. The latter is increasingly associated with a unique symbiosis of phenomena, processes, achievements, losses and tendencies that have unambiguous assessment.

By using the examples of the developed countries, countries with transitional economies and the functioning of the Ukrainian economy, it is possible to confirm the existence of a complex web of conflicting trends in the field of social, labor and human development, including the following:

- the increased demand for highly skilled, creative staff as an important human capital coexists with increasing unemployment of low-skilled workers, who are also insufficiently mobile and not able to acquire new competencies required by modern production;

- the growing hypertrophic differentiation of the labor income of employees, which often exceeds the real differences in the levels of accumulated human capital and the results of its use;

- against the backdrop of improvement in the structure of jobs and a generally stable increase in the average employment income of employees, there is an expanding ghetto of marginal employment with inadmissible rewards for the work done that do not provide a decent living. Poverty among the employed people remains high becoming a factor that reduces a social cohesion of society;

- there are multi-dimensional and wide-scale changes on the labor market, which, however, are not always in the interests of employees. Thus, there is an unprecedented growth in the use of non-standard forms of employment, the types of work schedules and atypical employment contracts. The expansion of these forms of employment and employment contracts is often a consequence not of the real changes in the structure of organizational and economic peculiarities of production, but of the weakening balance of forces among employers and employees as a result of weakness (inadequateness) of the national labor legislation and reduction of the role of social dialogue. Labor legislation tends to liberalization, while collectively-contractual regulation does not cover the whole variety of employment forms;

- there are obvious signs of de-socialization of social and labor relations, the expression of which is: reduction of the share of wages and salaries in the GDP of many countries, including the developed ones; complications in public access to the previously existing forms and types of social protection; increase in employees' contributions to social insurance funds; attempts of authorities to resolve the problems arising from the deterioration of demo-economic indicators by shifting the burden on the working people;

- the interests of improving the competitiveness of the economy and creating conditions for sustainable social development need an increased attention to the problems of socially responsible behavior of business. However, the proportion of businesses that systematically 
maintain their image, working hard to improve the reputation and conduct their operations on the principles of social responsibility, remains low;

- the major segments of the social structure of society are becoming increasingly different in terms of their well-being, lifestyle and behavioral norms. The split of society exacerbated by economic globalization in its current form complicates the formation and functioning of democratic institutions of the state and civil society as the foundation of democracy is undermined - social harmony regarding the basic values and principles of life.

It should be noted that the world, in general, and the world of work, in particular, are becoming increasingly polarized, stratified, differentiated, and, thus, more and more unstable and unfair. In these conditions, asymmetries are no longer the exception, but the rule.

\section{Forms of manifestation of the decent work deficit}

The latest financial crisis and subsequent permanent crisis phenomena created new problems in the development of social and labor sphere, which contribute to the preservation of the decent work deficit. We are talking about massive violations on the part of employers, such as:

- dismissals due to biased explanations (repeated failure to fulfill job responsibilities, nonconformity of the employee's competencies to the existing requirements based on the results of certification);

- forced resignation of an employee instead of personnel reduction procedures without the payment of compensations;

- unilateral change of the terms of employment contracts (lowering of wages, reduction of the costs of providing safe working conditions, forcing employees to sign fix-term employment contracts);

- non-payment or late payment of wages;

- incomplete payment during dismissals;

- introduction of atypical working schedules that meet the needs of employers only;

- overtime work without payment or compensation.

Consequently, there is an increase in the asymmetry of rights and responsibilities, distribution of social costs and benefits of employers, on the one hand, and employees - on the other. For the formation of the balance of costs and benefits in their favor, employers seek informal or semi-formal relations in the labor sphere, which are becoming increasingly attractive for them.
There is a tendency to expand the range of informal rules and norms of behavior in the field of industrial relations, which are favorable to employers:

- overtime work without payment or compensation;

- wages "in envelopes";

- indefinite leave;

- reduced working week;

- atypical working schedule.

Regarding the existence of the deficit of decent work, we should note the following: forms of manifestation of decent work deficits are becoming more diverse, while the extent and the depth of this manifestation is growing. It is evidenced by the following:

- permanent growth of unemployment in the open or hidden forms;

- growth of non-standard forms of employment and atypical employment contracts without proper social protection;

- increase in the share of jobs that do not give a socially acceptable level of income;

- poor working conditions and increasing social vulnerability of employees with different forms of manifestation;

- increase in the scope and depth of asymmetries in the social and labor sphere, which create the conditions for the growing deficit of decent work.

An important component of the decent work deficit is the deepening deformations in the relations of distribution, including the distribution according to the level of work and capital, and in the allocation of capital. Extremely deformed distribution relationships produce rising inequalities in various forms.

We have given a non-complete list of features of industrial relations, which are actually functioning in the modern world and which have a negative impact on the institution of decent work. In this situation, employees have to be in two "worlds of work". The first one is a formal world, which has a valid employment contract and which declares the rights of working people, and the second one is the real world with its informal or semi-formal relationships and actions that are contrary to the agreements reached during the contract signing. The economic science has proved that economic and social development, economic and social progress have a one-vector dynamics when economic achievements are accompanied by social transformations and when such harmonious development concerns the interests of the absolute majority of people manifested primarily in the social and labor sphere. 


\section{Reasons for the deficit of decent work in Ukraine}

The reasons that destabilize the social and labor sphere in Ukraine are at the same time, the reasons that limit the development of the institute of decent work. They include the following:

1) globalization of the world economy in its present form and ambiguities of the consequences of its impact on the institute of decent work;

2) liberalization of socio-economic policy, the component of which is the so-called economocentrism. The consequences of it are the prevalence of economic over social, the dominance of the state in which economic expediency takes precedence over social orientation and the interests of the absolute majority of the population are relegated to the background;

3 ) formation of a new economy that fundamentally changes the established elements of the labor market (demand, supply, cost of labor services) and the mechanisms of its functioning, enhancing multi-dimensional changes on the labor market;

4) increasing segmentation of the social and labor sphere with coexisting pre-industrial, industrial and postindustrial methods of regulation;

5) transformation of the institute of employment and multi-dimensional changes on the labor market;

6) reduction of the role of social dialogue in optimizing the relationship between the major social forces. One of the consequences of this unintended trend is a widespread practice of monopolistic dictate on the part of employers, a massive neglect of the decent work principles;

7) low, inadequate needs of the present role of the state in ensuring sustainable development of social and labor sphere;

8) limited scope and formal format of introduction of the institute of social responsibility in the sphere of labor and industrial relations;

9) the crisis of values of society as a whole and work values in particular.

Among these factors, the most important ones are the transformation of the institute of employment and multi-dimensional changes of the labor market. Radical changes in the institute of employment are an objective response of the economic system and its social and labor component to the challenges of dynamic transformations - technological, organizational, motivational, demo-economic, consumer and others. At the same time, this is the evidence of development of relationships of the post-industrial economy (knowledge economy) in the functioning of modern labor market. The new hierarchy of factors of economic development, intensive introduction of new advanced technologies, especially information and communication ones, increasingly lead to the transformation of the forms of employment and the growing requirements to the subjects of economic activity. The strengthening of the role of human creativity in the production process contributes to the growing demand for intellectual, creative work, for highly skilled employees focused on permanent learning. Human capital becomes a key factor of economic development, the most effective economic resource. At the same time, one should remember that the constant growth of requirements to the training and mobility of employees is increasingly combined with the problem of underemployment of not sufficiently mobile citizens.

In Ukraine, as in most other countries, there is a deep transformation of employment. This means changes of its basic forms, types and content. The Ukrainian labor market gradually follows global trends.

\section{Global transformations of the institute of employment and their impact on the scope and quality of decent work in Ukraine}

The scale and quality of decent work is closely correlated with the radical changes that are taking place in the field of employment. The results of the research conducted by the authors make it possible to single out a number of interrelated processes that have taken place over the last 10-15 years and becoming increasingly important considering their scale and intensity by changing employment patterns and established labor market parameters and negatively affecting the institute of decent work, namely:

- the spreading of new, unconventional forms of employment and atypical models in organization of work time;

- increase of the labor market flexibility that extends to all of its parameters - demand, offer, the cost of work services;

- decentralization of collective-contractual regulation of relationships concerning employment;

- increased differentiation of the labor market segments with the coexistence of elements from pre-industrial, industrial and post-industrial eras;

- strengthening of the trend in which an essential share of jobs with high and ultra-high complexity exists with the same share of jobs with low and ultra-low complexity;

- multi-dimensional processes taking place in the content and nature of work. As in the early twentieth century there were hundreds of thousands of jobs on conveyor lines with monotonous primitive labor, on the threshold of 
the third millennium new jobs are emerging at offices and other structures, which use modern information technologies.

It should be noted that analytical materials on the economic activity of the population are increasingly filled with such terms as "vulnerable employment", "insecure employment", "nonstandard employment", "self-employment" and so on. This means that the established parameters of the labor market and employment, which dominated in the twentieth century right up to the 80-ies, are filled with other characteristics.

The Human Development Report for 2014, entitled "Sustaining Human Progress: Reducing Vulnerabilities and Building Resilience", prepared by UNDP, notes that worldwide nearly half of all employees work under conditions of vulnerable employment and typically are not subject to the jurisdiction of labor legislation and social protection. Over the years, in response to economic instability and periodic crises, employers are increasingly using part-time or temporary employment. The same report notes also that a large proportion of "working poor" is covered by non-standard forms of employment: in the developed countries - forced part-time and temporary employment, and in the developing countries - informal employment (Human Development Report, 2014). Here are some examples and data that reflect very contradictory and often negative consequences of transformations of the institute of employment in its global dimension, including in Ukraine. The growing segment of the labor market in countries with transitional economies and in the developed countries is a selfemployment sector. The institute of selfemployment on the Ukrainian labor market is developing in line with the general trends characteristic of transitional countries. Its dynamic development began with the beginning of economic reforms and is the result of two main factors. One of the segments of self-employed workers is represented by employees who have consciously chosen this type of employment as corresponding to their interests and making it possible to obtain certain benefits and advantages:

- to ensure manufacturing independence;

- to realize the existing ideas and projects;

- to achieve a higher level of income compared to the market price of labor services for the employed people;

- to take advantage of favorable tax conditions and other preferences.

The second segment of self-employed consists of person for whom this type of employment has a forced nature due to the shortage of decent jobs on the labor market. According to the data of special surveys, there is a particularly high proportion of those people who have not been hired in transitional countries, including Ukraine. According to Fields (1990), such forced self-employment is the bottom tier of employment that should be rightly regarded as a kind of alternative to unemployment. Depending on which group of factors dominates in shaping the institution of self-employment, one determines the economic role of the latter, the socioeconomic situation of this group of people on the labor market, the level of social security and so on.

In the economic literature, which is devoted to the problems of the labor market and employment, there are ongoing debates about the optimal level of selfemployment in the market economy. Despite the diversity of opinions, most researchers share the view that a very high level of self-employment, that is, when its share reaches and even exceeds one third of the total number of jobs, is a sign of archaic economy and the lack of jobs in the formal sector.

A high proportion of self-employed people on the Ukrainian labor market is due to the fact that most of them were forced into entrepreneurship. The main goal of such people is to satisfy their current needs, while the problems of business expansion, development of the new types of activities and obtaining access to the new markets are not even considered (Eastern Partner Countries. Progress in the Implementation of the Small Business Act., 2011).

The above-mentioned materials confirm that the current Ukrainian labor market is a world of contrasts, a world of conflicting trends, a world of ambiguous transformations. But the list of events and processes that change the contours and format of the labor market, just like the world of work in general, can be extended. However, it is important to realize that the transformation of the institute of employment means a previously unprecedented scale in the use of non-standard (atypical, nontraditional) forms of employment, including:

- part-time employment;

- fixed-term employment contracts;

- temporary, unstable employment, including borrowed labor;

- secondary employment;

- remote employment;

- employment on the basis of independent contractor agreements;

- informal employment, including selfemployment;

- unregistered employment in the formal sector.

It should be noted in mind that the boundaries between different forms of non-standard employment are blurred and mobile. As for the concept of "nonstandard employment", in 
determining its nature and characteristics most labor market researchers rightfully use the reverse concept of "standard time". The latter means employment of full-time working day on the basis of indefinite employment contract and at a standard workplace.

Considering the nature of the phenomenon of nonstandard employment, it is necessary to note that its long-term and deep source is a symbiosis of two factors that exist in space and time. This refers to the fact that the need of more and more employers (demand for atypical employment) is combined with a simultaneous transformation of work offers.

The factors that produce an increased demand for atypical employment include:

- structural changes during the transition from mass assembly-line production to the production characteristic of the new economy (knowledge economy);

- increasing global competition;

- significant expansion of the service sector;

- previously unprecedented scale in the use of information and communication technologies;

- increase in the flexibility of the labor market and production.

Changes in the structure of labor services offers are stimulated by the following factors:

- increased involvement of women and youth, particularly students, in the economically active life;

- increasing household wealth;

- computerization and increasing technical equipment of households;

- gradual transformation of "economic person" into "creative person";

- increasing importance of non-material motives in the life of economically active population.

Our belief is that the expansion of non-standard employment is not a short-time anomaly and political miscalculation that can be easily eliminated by adopting appropriate "right" laws or other through the levers of economic policy. It appears to be a global trend that has deep social, economic, political and technical roots.

The development of non-standard forms of employment and instability of industrial relations are the main causes of the phenomenon called precarization, which, as practice shows, destabilizes the social and labor sphere, causing de-socialization of the relationship between labor and capital and "works" to reduce the quality of working life.

For the first time, precarization, as a social phenomenon, was noticed by researchers in the 80s. In the most general interpretation, precariat is a social group which finds itself in a difficult, unstable social situation. Accordingly, precariat representatives are all people who are in unstable labor relations, who are subject to non-standard (unstable, atypical, temporary, etc.) forms of employment and who eke out a living on social assistance. Regarding the term precarization, it can be interpreted as an extension of diverse forms of non-standard employment and, at the same time, as a social phenomenon that is associated with increasing layers of people who feel the precariousness, insecurity and instability of their condition and social life.

To a considerable degree, precarization is largely confined to deviations from: standard employment relationships; standard relations regarding labor income; standard security from social risks; standard, legally enforceable, labor rights.

Factors that contribute to the acquisition by economically active persons of the status of precariat:

- lack of stable jobs and insecurity;

- low labor income as a result of the forced nonstandard employment;

- reduction of social security;

- shadow economy at it impact on social and labor relations;

- erosion of labor rights;

- full or partial dismantling of the "standard" employment contract.

For a comprehensive description of the category of "precariat", in our opinion, it should be considered from at least four positions:

1) precariat is a category of economically active people, who are partially or fully excluded from the officially employed workforce and this exclusion has a forced character;

2) precariat - means economically active population that experiences social insecurity because of unstable employment;

3) precariat means economically active population in relation to which there is a full or partial dismantling of the "standard" employment contract that is not the initiative of the employee;

4) precariat means economically active population that is not able to realize its right to decent work.

The need for a systematic study of the phenomenon of precarization is dictated by the seriousness of its consequences both for employees and for the economy and society as a whole. For economic person, the status of precariat means not only material, but also moral, psychological and social losses. 
The losses of material nature are obvious: inability to provide decent living conditions, inadequate reproduction of labor, lack of prospects for human capital development and so on. Equally important is the loss of another nature: people increasingly feel excluded from public life, feel stressed, uncertain, lose the ability to plan the creation of a family, childbirth, children's education, purchase of durable goods, people feel insecure, alone with their problems. It should also be emphasized that in the conditions of non-standard employment, people lose peace of mind, become unhappy. The result is the deterioration of moral and physical condition of employees, the reduction of incentives, the quality of work and its results.

We share the opinion that the development of nonstandard forms of employment not only expands the experience of citizens in the field of employment making their economic behavior more variable, but also directs workers to making extra earnings that is associated with long-term physical and psychological overloads and depreciation of their qualification potential in those cases when additional work does not correspond to their main qualifications or falls far below their skill levels.

What is the size of precariat in Ukraine? Indicators characterizing the number of different categories of economically active population in the status of precariat (according to official statistical data 2006-2015) are listed in Table 1. For the purposes of international comparisons and evaluation of the level of precarization of the social and labor sphere in Ukraine, indicative is the share of different groups in the precariat status in the economically active population.
The major precariat groups in the economically active population in Ukraine consist of the unemployed and those employed in the informal economy in 2006-2015. We estimate that for this period from $27.6 \%$ to $32.9 \%$ of the economically active population of Ukraine can be attributed to precariat.

At present we see new forms and alarming scale of non-standard employment that prevent sustainable social dynamics and achievement of high standards in the quality of working life. Unstable employment and increase in precarization prevent the implementation of decent work principles. We assume that nonstandard forms of employment have a right to exist, in fact, we realize that the extent of implementation of these forms has to grow. After all, this is a form of adaptation of businesses to the conditions generated by globalization. At the same time, we maintain that the balance in the use of standard and non-standard forms of employment has been disturbed. Social and labor relations develop in asymmetrical ways with the "infringement" of right not of employers, but of employees.

\section{Institute of decent work as a complex political, economic and social platform for sustainable development}

The institute of decent work in its general institutional dimension should be seen as a comprehensive political, economic and social platform that should unite the efforts of public authorities and social partners on all levels of the hierarchical structure of the world and national economies, representative bodies of civil society so that the social and economic progress was ensured

Table 1. Indicators characterizing the categories of economically active population of Ukraine in the status of precariat in 2006-2015

\begin{tabular}{|c|c|c|c|c|c|c|c|c|c|c|}
\hline Indicator & 2006 & 2007 & 2008 & 2009 & 2010 & 2011 & 2012 & 2013 & 2014 & 2015 \\
\hline \multicolumn{11}{|c|}{ 1. Unemployed population aged $15-70$} \\
\hline Number, thousand people & 1515.0 & 1417.6 & 1425.1 & 1958.8 & 1785.6 & 1732.7 & 1657.2 & 1576.5 & 1847.6 & 1654.7 \\
\hline Share in the economically active population, $\%$ & 6.8 & 6.4 & 6.4 & 8.8 & 8.1 & 7.9 & 7.5 & 7.2 & 9.3 & 9.1 \\
\hline \multicolumn{11}{|c|}{ 2. People employed in the informal sector of the economy } \\
\hline Number, thousand people & 4623.3 & 4661.7 & 4563.8 & 4469.9 & 4649.2 & 4704.9 & 4651.6 & 4805.9 & 4540.9 & 4303.3 \\
\hline Share in the economically active population, $\%$ & 20.8 & 20.9 & 20.4 & 20.2 & 21.1 & 21.4 & 21.1 & 21.9 & 22.8 & 23.8 \\
\hline \multicolumn{11}{|c|}{ Employed people, whose salary is within the minimum wage limits } \\
\hline Number of staff employees, thousand people & 879.7 & 640.5 & 825.7 & 882.8 & 791.5 & 603.6 & 557.4 & 517.4 & 351.7 & 221.5 \\
\hline Share in the economically active population, $\%$ & 4.0 & 2.9 & 3.7 & 4.0 & 3.6 & 2.7 & 2.5 & 2.4 & 1.8 & 1.2 \\
\hline \multicolumn{11}{|c|}{ 4. Employees working under independent contractor agreements } \\
\hline Number, thousand people & 323.5 & 307.0 & 250.3 & 238.7 & 258.1 & 277.7 & 257.9 & 239.3 & 227.1 & 217.4 \\
\hline Share in the economically active population, $\%$ & 1.5 & 1.4 & 1.1 & 1.1 & 1.2 & 1.3 & 1.2 & 1.1 & 1.1 & 1.2 \\
\hline
\end{tabular}

\footnotetext{
${ }^{1}$ Note. Without the number of illegal immigrants.
} 
Table 1 (cont.). Indicators characterizing the categories of economically active population of Ukraine in the status of precariat in 2006-2015

\begin{tabular}{|c|c|c|c|c|c|c|c|c|c|c|}
\hline Indicator & 2006 & 2007 & 2008 & 2009 & 2010 & 2011 & 2012 & 2013 & 2014 & 2015 \\
\hline \multicolumn{11}{|c|}{ 5. Employees, who are not covered by collective agreements } \\
\hline Number, thousand people & 2002.4 & 2049.7 & 1877.6 & 1733.4 & 2022.8 & 1983.4 & 1969.6 & 2085.1 & 2156.5 & 1862.5 \\
\hline Share in the economically active population, $\%$ & 9.0 & 9.2 & 8.4 & 7.8 & 9.2 & 9.0 & 8.9 & 9.5 & 10.8 & 10.3 \\
\hline \multicolumn{11}{|c|}{ 6. Employees, who were on leave without pay } \\
\hline Number, thousand people & 137.0 & 127.0 & 180.0 & 275.9 & 363.3 & 189.5 & 137.9 & 103.5 & 90.5 & 62.6 \\
\hline Share in the economically active population, $\%$ & 0.6 & 0.6 & 0.8 & 1.2 & 1.6 & 0.9 & 0.6 & 0.5 & 0.5 & 0.3 \\
\hline \multicolumn{11}{|c|}{ 7. People who are not employed a full day (week) } \\
\hline Number, thousand people & 620.0 & 506.0 & 1206.0 & 2063.3 & 1466.8 & 908.9 & 736.8 & 817.5 & 888.1 & 742.1 \\
\hline Share in the economically active population, $\%$ & 2.8 & 2.3 & 5.4 & 9.3 & 6.7 & 4.1 & 3.3 & 3.7 & 4.5 & 4.1 \\
\hline \multicolumn{11}{|c|}{ 8. Seasonal employees } \\
\hline Number, thousand people ${ }^{2}$ & 36.3 & 31.3 & 25.8 & 27.9 & 31.1 & 20.2 & 44.7 & 23.7 & 19.9 & 18.1 \\
\hline Share in the economically active population, $\%$ & 0.2 & 0.1 & 0.1 & 0.1 & 0.1 & 0.1 & 0.2 & 0.1 & 0.1 & 0.1 \\
\hline \multicolumn{11}{|c|}{ 9. Workers, whose working conditions do not meet sanitary standards } \\
\hline Number, thousand people & 1420.9 & 1512.1 & 1410.8 & 1309.4 & 1300.7 & 13.3 & 1198.5 & 1186.7 & 1075.7 & 1040.5 \\
\hline Share in the economically active population, $\%$ & 6.4 & 6.8 & 6.3 & 5.9 & 5.9 & 5.8 & 5.4 & 5.4 & 5.4 & 5.8 \\
\hline
\end{tabular}

Note: Calculated according to the statistical data "Economic activity of the Ukrainian population" and "Labor Ukraine" [State Statistics Service of Ukraine] - Electronic resource. - Access mode: http://ukrstat.gov.ua/.

by the functioning of productive, knowledge-driven jobs, improvement of the working conditions, socialization of labor relations, empowerment of employees, development of their capabilities.

Within the framework of the common approach to the issue of decent work in different socio-economic formations an integral criterion for decent work at the global level for the poorest member countries of the ILO can be the provision of employment opportunities, and for the developed countries - provision of the quality employment according to the relevant standards of competitiveness of jobs and the guarantees of the workers' rights and equal opportunities. According to these criteria, we conduct the selection of common indicators for all ILO member countries grouped according to homogeneity of the economy based on the integral index of human development using partial indexes that enhance the objectivity of the assessment.

The basis for the introduction of the decent work institute at macroeconomic level in Ukraine should be the national initiatives to reduce the deficit of decent work and to realize the European standards of working life. Based on this message, decent work at the macro level is a socially useful, productive labor in the formal sector of the economy carried out under the conditions of a perfect social organization of labor providing access to decent jobs considering the human development of working people.

The main targets of achieving the European standards of working life have been outlined in memoranda of understanding in the field of employment, social policy and equal opportunities, which demonstrate the

${ }^{2}$ Note. Without the number of people engaged in private agricultural farms. formation of a global outline in the Ukrainian economy and society. In the context of European integration processes, a decent work concept aimed at ensuring the improvement of the quality of human life should include such components as increasing the number and improving the quality of jobs with decent working conditions; promotion of social and legal justice in the context of the labor market reform; facilitating the creation of conditions on the labor market that would combine flexibility and security; stimulating the development of inclusive labor markets, which are conducive to the engagement of socially vulnerable people; reducing the size of informal economy by transforming illegal employment; improving health protection and providing safe working conditions; modernization of social security systems regarding their quality, accessibility and financial stability; reducing poverty and strengthening social unity; ensuring gender equality and equal opportunities, overcoming discrimination in all its forms and manifestations; strengthening the capacity of social partners and promoting social dialogue (International document, 2014; Agreement on Association between Ukraine and the European Union, the European Atomic Energy Community and their Member States).

The significance of decent work in developing social and labor sphere lies primarily in the fact that the implementation of its principles is aimed at achieving both economic and social progress. Decent work is vital for all parties and actors of industrial relations. Regarding the employees, the implementation of decent work programs provides access to jobs and productive employment. The latter, in turn, is the key to solving the strategic problems of poverty among the working people and consistent improvement of the quality of working life. 
The urgent need for realization of the decent work principles is confirmed by the surveys of economically active population on their priority values related to labor, employment and conditions of its implementation. Thus, the materials of the survey conducted by the Research Center Pew Global Attitudes Project show that the priority values of the economically active population include job satisfaction and the priority of employment as a whole (Pew Global Attitudes Project: "Happiness is increasing in many Countries - but Why?"). Noteworthy are the results of the global study conducted in 79 countries, which was intended to give an answer as to which characteristics of jobs have the preference of the working people. According to these studies, the three most frequently mentioned characteristics of jobs are decent income (more than 8 out of 10 respondents), stable employment (more than 7 out of 10 respondents), conformity of a job to the person's skills and internal preferences (more than 6 out of 10 respondents) (European Values Study Group and World Values Survey association).

For employers, the realization of decent work principles is a prerequisite for realizing the mission of the organization. Decent work is crucial for acquiring competitive advantages, ensuring sustainable economic development. For the state and society the principles of decent work make it possible to create a strong economic foundation for social policy and, at the same time, a strong social orientation of economic policy. It is also a method of achieving and distributing the fruits of progress, the basis of a balanced, socially oriented development model.

Implementation of the principles of decent work is directly related to overcoming excessive inequality in incomes of the economically active population. Statistical data and special studies demonstrate that rising inequality is correlated with the deficit of decent work (Table 2).

Table 2. Data, which characterize regional disparities (inequalities) in the income of the population and their relation to the deficit of decent work *

\begin{tabular}{|l|c|c|c|}
\hline Jinny coefficient & Level of inequality & Regional structures & $\begin{array}{c}\text { Levels of deficit of decent work } \\
\text { in the corresponding regions }\end{array}$ \\
\hline$<0.3$ & Low & Central, Northern, North-Eastern continental Europe & Relatively low \\
\hline $0.3-0.4$ & Average & $\begin{array}{c}\text { Mainly Southern Europe, Anglo-Saxon countries, the Baltic states, } \\
\text { some Asian countries }\end{array}$ & Average \\
\hline $0.4-0.5$ & High & CIS countries, many countries in Asia, Latin America and Africa & High \\
\hline$>0.5$ & Very high & Mainly countries in Latin America and Africa & Very high \\
\hline
\end{tabular}

* According to the materials the International Labor Organization.

Realization of the principles of decent work has a direct relation to the progressive changes in the social stratification of society and especially to the creation of a strong middle class. Consistent expansion of the decent work segment is the shortest way towards reduction of poverty among the working population and overcoming of various manifestations of inequality and discrimination.

\section{Inclusive labor markets and their role in expanding the scale of decent work}

We emphasize that the possibilities of access to decent jobs are reduced as a result of several reasons.

The first reason is connected to a deficit of decent jobs. With the formation of the new economy, the scale of creation of new, decent jobs and reduction of the traditional ones is changing in favor of the latter.

The second reason, which considerably limits the access of a growing number of economically active people to decent jobs, is an increasing asymmetry between people's requirements to take a particular job and the existing abilities of the labor resources, insufficient intellectual and innovative components in the competences of those people who lay claims on decent jobs.
A global problem of the labor market and, therefore, of decent work is the growth of unemployment. This primarily concerns the younger generation, which for the first time finds itself on the labor market. Even the problem of the "working poor", which has extremely intensified in the last few decades, takes a back seat compared with the situation on the youth labor market. There are more than a dozen reasons for this, but the major ones are related to the shortage of decent jobs and the emergence of a new technological structure that leads to the reduction in labor-intensiveness of production resulting in job losses.

It is not a futuristic prediction, but a possible real scenario, which is actively discussed by theorists and practitioners and that is known as a 20:80 ratio, according to which the new economy will require no more than $20 \%$ of the economically active population. Probably, this assessment is unduly pessimistic. However, the results of almost all empirical studies, both theoretical and applied, demonstrate that a new economy with its information and communication, networking and nanotechnology components will increasingly cause significant changes in the structure and scope of employment. 
In the recent years, in the government structures and among the representatives of the parties of social partnership in many countries, there are active discussions going on about the so-called "inclusive markets", "integration policies", overcoming of social isolation. For example, discussions and practical actions regarding the development of "inclusive markets", carried out in Brazil in the recent years, are centered on the access of small businesses to training, new technologies, financial resources and network cooperation. The Minister of Strategic Affairs of Brazil Roberto Unger, in his interview to the Financial Times on December 10, 2007 emphasized that: "Today, in many areas of national life, we need not only to regulate or compensate disadvantages related to unequal rights on the market, but also to reorganize the market, to give it a new impetus, to make it more inclusive, the industrial policy and integration is the first step in the necessary direction".

For all the importance of a whole number of conditions and ways of decent work realization, it is necessary to understand that the main road to decent work goes through the creation of new and development of the existing sustainable and competitive economic entities that could provide decent jobs with decent working conditions, decent remuneration for work, adequate social protection and ensuring equality and freedom.

This concept should be dominant in all programs, doctrines and strategies regarding the development of the decent work institute. Without exaggeration, the most appropriate policy in the field of decent work is a highly professional and innovative general economic policy to ensure the competitiveness of the national economy based on knowledge-intensive jobs and the latest technologies that need appropriately qualified workforce. This vector of development of the economic activity and the labor market is constantly emphasized in the program materials of the International Labor Organization in its appeals to political elites and social partners at all levels.

It should be noted that whichever global peopleoriented goals we set for ourselves, they should be coordinated with the possibilities and prerequisites of social and labor development. An economic entity that produces goods or provides services operating on the global open market must have competitive advantages. Ways of acquisition of these advantages may vary. At one end, it is possible to have innovative development with high productivity, highly-qualified employees, knowledge-based products, high labor costs, which, combined with the efficiency of business activities do not increase the price of products, high labor mobility, etc. Another development strategy is the production of low added-value goods, low costs of labor force and low social spending. It should be noted that, in their pure form, these two strategies of ensuring competitiveness do not happen often. In reality, we have a combination of different strategies and, as the experience shows, winning in the competition are mostly those business entities that rely on innovative development and high social standards.

The latest global financial crisis and the permanent crisis phenomena accompanying the development of national economies, stagnation, which is experienced by the world economy, had to convince the political elite and everyone on whom depends the formulation and implementation of social and economic policies, that the main vector of the society's development should be a social and labor perspective, that the foundation of social policy at the present stage should be its social and labor component, that productive employment, decent remuneration for labor services and adequate social protection should be seen as global priorities.

We have to admit that due to the reasons of both objective and subjective nature the institute of decent work does not possess a stable dynamics. This is especially true in the developing countries, and countries with transition economies, including Ukraine.

\section{Strategic objectives in overcoming the decent work deficit}

The declaration by the International Labor Organization of the concept of decent work, numerous decisions and resolutions of this authoritative international organization are mostly a political appeal. So far, there are no instruments of the macro- and microeconomic policies focused on productive employment, creation of decent jobs and improvement of the opportunities for the working people. In the public mind, there is a very slow realization that decent work prospects are associated not with informal, but with formal sector of the economy, not with informal, but formal employment that cannot cross the "red line" in the use of nonstandard forms of employment generating a number of social and economic risks. It is the deficit of decent work that is the main cause of degradation of the social and labor sphere, while poverty, social isolation, social exclusion, lack of social cohesion and lack of social stability have the same roots.

The development of the institute of decent work is associated with the creation of employment opportunities, with free and productive labor, with its safety and equality at work.

Decent employment opportunities are, first of all, an increase in the size of the formal economy, official employment with compliance with the requirements that are not interchangeable, but complementary. In our vision, the mechanisms of the informal economy's 
functioning (legal, economic, institutional, ethical, etc.) form and constantly recreate the conditions in which the simultaneous presence of all signs of decent work are impossible. Such position is consistent with the political statements of the governing institutions of the International Labor Organization, conference materials of this organization (Decent Work and the informal economy, 2002).

It is our deep conviction that improvement of employment opportunities should be based on increasing the scope of the tertiary sector and the sphere of innovation, improving the competitiveness of knowledge-based workforce, which, in turn, ensures a comprehensive professional development of employees and their decent remuneration.

The growth of atypical types of employment as one of the contemporary trends in the development of the social and labor sphere at the global level and in the context of decent work, according to the authors, should be subject to the following requirements:

- atypical employment should be conducted on the basis of a voluntary choice of an employee;

- social guarantees for non-standard employment should at least be adequate to the guarantees provided by the traditional employment, they cannot have an undetermined status;

- unacceptable is the abuse by employers of employees in atypical employment status;

- negative effects arising from the development of atypical forms of employment should be offset by the implementation of appropriate methods of social protection.

The implementation of the principles of free labor as a labor without coercion means guarantees on the choice of employment forms and freedom to organize associations.

Productive labor as a component of the concept of decent work requires a high level of return for all parties to industrial relations from the use of employment potential manifested in the growth of macro- and microeconomic indicators, provision of decent remuneration for work results with a balanced satisfaction of the parties' interests.

Labor protection guarantees social security (health insurance, pensions, benefits, financial support in case of accidents and diseases at work), compliance with sanitary conditions and safety at the workplace.

Equality at work is possible in the case of creation of equal opportunities of access to jobs and the guaranteed absence of all forms of discrimination based on age and gender differences, as well as limited physical abilities of people.

\section{Conclusions}

Under the influence of a number of factors, both internal and external, the world of labor and industrial relations changes in extremely controversial ways, and the process of such changes will intensify. This dictates the need for comprehensive, impartial, unbiased analysis of the transformation of social and labor sphere, separation of characteristic tendencies, trends, dominants social and labor development.

The research conducted by the authors proves that the deficit of decent work is one of the most pressing problems of the modern economy and its institutions. The new format of the decent work concept actively developed by the study's authors must, firstly, become a ramified system of scientific views on the philosophy of development of the world of labor based on the principles of decent work; secondly, to become a basis for the development of institutional support for decent work; thirdly, to acquire the status of a platform, on the basis of which a public-contractual and managerial leverage of the main components of decent work will be formed.

The modern philosophy of decent work and its principles of social and economic mechanisms to overcome the deficit in this area should be seen, in our vision, as a democratic requirement to government bodies and social partners at all levels to create decent jobs, ensure access to the them and create the appropriate conditions (legal, organizational, economic, institutional, physiological, etc.) for productive employment. This requirement is aimed at overcoming the deficit of decent work and further development of the social and labor sphere.

We believe that the updated concept of decent work must absorb theoretical and applied developments, which are conducted with direct participation and support of the International Labor Organization and other international institutions in the field of social and labor development and, at the same time, to take into account the latest trends in the transformation of the social and labor sphere, to prevent fragmentation, the vagueness of the previous groundwork and to provide the institutions of economy and society with a clear doctrine of changes in the social and labor sphere.

\section{Areas for further research}

Theoretical and methodological foundation of the concept of decent work proposed to the readers are the result of the first phase of the research project "Social and economic mechanisms of ensuring decent work under the conditions of the European integration processes and innovative investment model of economic development of Ukraine" has been reflected in the publications of the paper's authors (Kolot \& Herasymenko, 2015). The formation of an updated concept of decent work is carried out taking into account the fact that the achievement of the decent work objectives is a two-pronged process of 
combination and interaction of its components (access to decent jobs, safe, favorable working conditions, empowerment of employees, etc.) with potential external conditions to consolidate decent work principles (economic, social, legal, institutional, etc.) that are created at all levels of the hierarchical structure of the economy and society with the support of state institutions and social partnership.

In addition to the world's scientific and applied achievements in identifying decent work, the authors have developed proposals regarding the socioeconomic dimension of decent work considering the current national economic transformation in Ukraine (Kolot, \& Herasymenko, 2016) and shown the interconnection between the decent work deficit and the crisis of values (Kolot \& Herasymenko, 2016).
Under the existing conditions, representatives of scientific schools, primarily the schools of social and labor orientation, should give increased attention to the problems of progress in the field of labor in the new economy and post-industrial society; to build a road map expanding the possibilities of decent work. We have to build a new concept of decent work abandoning the obsession with growth without development. Scientific results, as well as practical and theoretical calculations presented in this article serve as a basis for further scientific and applied research regarding the mechanisms and instruments of decent work under the conditions of creation of the new economy and the European integration processes.

\section{References}

1. Anker, R., Chernyshev, I., Egger, P., Mehran, F., \& Ritter, J. (2002). Measuring Decent Work with Statistical Indicators, Working Paper, 2, International Labour Office, Geneva.

2. Bescond, D., Chataignier, A., \& Mehran, F. (2003). Seven indicators to measure decent work: An international comparison. International Labor Review, 142(2), 179-212. https://doi.org/10.1111/j.1564-913X.2003.tb00258.x

3. Bonnet, F., Figueiredo, J., \& Standing, G. (2003). A family of decent work indexes, International Labor Review, 142(2), 213-238. https://doi.org/10.1111/j.1564-913X.2003.tb00259.x

4. Decent Work and the informal economy (2002). Report VI submitted to the 90th Session of International Labour Conference, Geneva.

5. Decent Work Country Profile: Ukraine. (2013) / International Labour Office, ILO/EC Project "Monitoring and Assessing Progress on Decent Work". Geneva. ILO.

6. Decent work Deficit: A global challenge Report of the Director-General Reducing the International Labour Conference (2001). 89th Session International Labour Office. Geneva.

7. Decent work for all in a global economy. (1999). Retrieved from http://www.ilo.org/public/english/bureau/dgo/speeches/somavia/1999/seattle.htm.

8. Decent work in the information economy. (2000). Report of the Director-General, Geneva.

9. Decent work. Report of the Director-General. International Labour Conference. (1999). 87th Session. International Labour Office, Geneva.

10. Decent work: Some Strategic Challenges Ahead. Report of the Director-General. International Labour Conference (2008). 97th Session. International Labour Office, Geneva.

11. Eastern Partner Countries. Progress in the Implementation of the Small Business Act (2011). Paris.

12. European Values Study Group and World Values Survey association : European and World Values Survey World Values Surveys four-wave integrated data file 1981-2004 (2006).

13. Fields, G. (2003). Decent work and development policies. International Labour Review, 142(2), $239-262$. https://doi.org/10.1111/j.1564-913x.2003.tb00260.x

14. Fields, G. (1990). Labour market modelling and the urban informal sector: Theory and evidence. In Turnham, D., Salom, B., \& Schwarz, A. (Eds.), The informal sector revisited (pp. 49-69). Paris: Organisation for Economic Cooperation and Development.

15. Ghai, D. (2003). Decent work: Concept and indicators. International Labor Review, 142(2), 113-145. https://doi.org/10.1111/j.1564-913x.2003.tb00256.x

16. Hostiuk, O. (2016). The concept of decent work as part of legal state policy. Pidpryiemnytstvo, hospodarstvo $i$ pravo, 6, 90-93.

17. Human Development Report 2014 (2014). Sustaining Human Progress: Reducing Vulnerabilities and Building Resilience. New York, UNDP.

18. Humeniuk, N. (2011). Fundamental principles of formation of decent work. Naukovyj visnyk Poltavs'koho universytetu ekonomiky i torhivli. Seriia: Ekonomichni nauky, 4, 68-72.

19. Husiev, A. (2014). Protection of labour as a component of the decent work. Visnyk Natsional'noho tekhnichnoho universytetu Ukrainy “Kyivs'kyj politekhnichnyj instytut”. Seriia: Hirnytstvo, 26, 134-141.

20. Il'ienko, N. (2014). Employment opportunities as one of the progressive trends for providing the existence of decent work in Ukraine. Naukovi pratsi Natsional'noho universytetu kharchovykh tekhnolohij, 4, 111-123.

21. ILO. (2000). Decent work pilot program. Retrieved from: http://www.ilo.org/public/english/bureau/dwpp/.

22. International document (2014). Agreement on Association between Ukraine and the European Union, the European Atomic Energy Community and their Member States. Retrieved from: http://zakon4.rada.gov.ua/laws/show/984_011.

23. International Labour Conference, 103rd Session. (2014). Report V(1) Transitioning from the informal to the formal economy Fifth item on the agenda International Labour Office Geneva.

24. Kalachova, I. (2006). Conceptual and methodical aspects of measuring of decent work. Ekonomika promyslovosti, 3, 229-234. 
25. Kaplina, H. (2013). Features the concept of decent work in Ukraine. Aktual'ni problemy prava: teoriia i praktyka, $26,47-54$.

26. Kolot, A., \& Herasymenko, O. (2015). Theoretical and methodological basis of decent work: problems and directions of development. Sotsial'no-trudovi vidnosyny: teoriia ta praktyka, 2(10), 21-42.

27. Kolot, A., \& Herasymenko, O. (2015). Decent work as a concept and strategic direction of the development of social and labor sphere. Ukrayina: aspekty pratsi, 6, 3-13.

28. Kolot, A., \& Herasymenko, O. (2016). Values of working life and decent work: the philosophy of cooperation and development. Ukrayina: aspekty pratsi, 1-2, 3-13.

29. Kolot, A., \& Herasymenko, O. (2016). Socio-economic dimension of decent work in the coordinates of the new economy. Ukrayina: aspekty pratsi, 3-4, 10-24.

30. Lebediev, I. (2014). Corporate social responsibility in the context of decent work, Atlant VOI SOIU, Odessa, Ukraine.

31. Measuring decent work. Decent Work Country Profiles. Retrieved from: http://www.ilo.org/integration/themes/mdw/lang--en/index.html.

32. Pew Global Attitudes Project : "Happiness is increasing in many Countries — but Why?", 24 July 2007. Retrieved from: www.pewglobal.org

33. Rudakova, S. (2012). Decent work as the factor of development of socially oriented economy in Ukraine. Ukrains'kyj sotsium, 2, 121-134.

34. Shaul's'ka, L. (2014). Implementation of the Concept of decent work on the basis of ensuring competitiveness of human capital assets. Visnyk Pryazovs'koho derzhavnoho tekhnichnoho universytetu. Seriia: Ekonomichni nauky, $28,278-283$.

35. Zhadan, O. (2014). The concept of decent work as the foundation of social and economic development of the country. Teoriia ta praktyka derzhavnoho upravlinnia, 2, 8-15. 